\title{
THROWING GOOD MONEY AFTER BAD? BOARD CONNECTIONS AND CONFLICTS IN BANK LENDING
}

\author{
Randall S. Kroszner \\ Philip E. Strahan \\ Working Paper 8694 \\ http://www.nber.org/papers/w8694 \\ NATIONAL BUREAU OF ECONOMIC RESEARCH \\ 1050 Massachusetts Avenue \\ Cambridge, MA 02138 \\ December 2001
}

We would like to thank Gary Gorton, Raphael de la Porta and an anonymous referee for useful comments. Kroszner would like to thank the Lynde and Harry Bradley Foundation for research support. Comments welcome. The views expressed herein are those of the authors and not necessarily those of the National Bureau of Economic Research.

(C) 2001 by Randall S. Kroszner and Philip E. Strahan. All rights reserved. Short sections of text, not to exceed two paragraphs, may be quoted without explicit permission provided that full credit, including (C) notice, is given to the source. 
Throwing Good Money After Bad?

Board Connections and Conflicts in Bank Lending

Randall S. Kroszner and Philip E. Strahan

NBER Working Paper No. 8694

December 2001

JEL No. G3

\begin{abstract}
This paper investigates the frequency of connections between banks and non-financial firms through board linkages and whether those connections affect lending and borrowing behavior. Although a board linkages may reduce the costs of information flows between the lender and borrower, a board linkage may generate pressure for special treatment of a borrower not normally justifiable on economic grounds. To address this issue, we first document that banks are heavily involved in the corporate governance network through frequent board linkages. Banks tend to have larger boards with a higher proportion of outside directors than non- financial firms, and bank officer-directors tend to have more external board directorships than executives of non- financial firms. We then show that low-information cost firms -- large firms with a high proportion of tangible assets and relatively stable stock returns -- are most likely to have board connections to banks. These same low- information cost firms are also more likely to borrow from their connected bank, and when they do so the terms of the loan appear similar to loans to unconnected firms. In contrast to studies of Mexico, Russia and Asia where connections have been misused, our results suggest that avoidance of potential conflicts of interest explains both the allocation and behavior of bankers in the U.S. corporate governance system.
\end{abstract}

Randall S. Kroszner

Graduate School of Business

University of Chicago

1101 East 58th Street

Chicago, IL 60637

and NBER

randy.kroszner@gsb.uchicago.edu
Philip E. Strahan

Carroll School of Management

Boston College

140 Commonwealth

Chestnut Hill, MA 02467

philip.strahan@bc.edu 


\title{
THROWING GOOD MONEY AFTER BAD? BOARD CONNECTIONS AND CONFLICTS IN BANK LENDING
}

\author{
Randall S. Kroszner and Philip E. Strahan
}

August 2001

\section{Introduction}

Connections between banks and potential borrowers raise important issues in both economic theory and regulatory practice. Connected lending occurs when the lender has more than a simple arm's length relationship with the borrower. One potentially important connection in the U.S. occurs through the board of directors. Although a board linkage may provide the benefit of better information flows between a borrower and lender, a person on the board of both a bank and a borrowing firm may face a conflict of interest: the person has a fiduciary duty to both the bank and the firm and these interests may diverge. In particular, regulators are concerned that such connections could lead banks to "throw good money after bad" by favoring connected firms that become distressed and thereby expose the deposit insurer and taxpayer to unduly large losses. Connections between banks and potential borrowers thus involve a tradeoff in which the benefits of better information must be weighed against the costs of worsened conflicts.

Economic and finance theory does not tell us how this tradeoff is resolved. Lamoreaux (1994) argues that connected lending was important to the development of U.S. banking during the nineteenth century because it was an efficient mechanism for reducing monitoring and enforcement costs. Hoshi, Kashyap and Sharfstein (1991) argue that firms in Japan connected to 
their bank through a keiretsu were insulated from cash flow shocks that could distort investment choices. Both of these studies suggest that the information benefits of connections outweigh the costs of conflicts.

Other studies suggest, however, that conflicts associated with connected lending are the primary reasons for the fragility of many financial systems. Rajan and Zingales (1998), for example, argue that much of the collapse of the Asian tigers in 1997 and 1998 was due to connected lenders continuing to extend credit to distressed borrowers rather than cutting off bad credits early and forcing restructuring before problems grew out of control. La Porta, Lopez-deSilanes, and Zamarripa (2001) argue that connected lending in Mexico was tantamount to looting of the banks. Laeven (2001) finds that connected lending in Russia during the 1990s also exposed banks to undue risks.

In this paper we argue that in the United States, just as in the emerging economies, the potential for conflicts can explain bank connections to potential borrowers. U.S. legal and regulatory doctrines designed to punish bankers that exploit their position, along with effective protection of shareholder rights, however, raise the cost of exploiting conflicts here. ${ }^{1}$ Thus, rather than see bankers taking advantage of their connections, in the U.S. we show that bankers avoid connections with firms where the temptation to exploit information and control would be greatest. We also show that banks with connections avoid lending to firms where the potential for exploitation of information would be greatest.

${ }^{1}$ More broadly, La Porta, Lopez-de-Silanes, Shleifer, and Vishny $(1998,1999)$ argue that the degree of the protection of the rights of shareholders and creditors can explain differences in capital market development, ownership concentration, and firms' access to external finance. 
We begin by establishing the prevalence of connections between banks and large U.S. firms. U.S. banks have both larger boards and a higher proportion of outside directors on their boards than do non-financial firms of similar size. Also controlling for size, executive s of banks have a higher propensity of external directorships (that is, sit on the boards of other firms) than do executives of non-financial firms. Banks thus appear to be heavily involved in the corporate governance system in the U.S.

Following Kroszner and Strahan (forthcoming), we next explore the allocation of bank connections to firms. Consistent with $\mathrm{K} \& \mathrm{~S}$, we find that firms with board connections to banks tend to be the low information-cost firms that are unlikely to "bank dependent." Specifically, large and stable firms with relatively high proportions of tangible assets are more likely to have a bank connection than small, risky and opaque firms. We also find, however, a non-linear relation between the presence of bank connections and volatility. The likelihood that a firm has a bank connection first increases, then decreases, with volatility, suggesting that at low levels of risk the benefits of monitoring appear to dominate, while at higher levels of risk, the conflict of interest costs become more important. We extend $\mathrm{K} \& \mathrm{~S}$ by exploring connections in which a firm executive serves on a bank's board, as well as connections in which a banker serves on a non-financial firm's board. The results suggest that both kinds of connections reflect efforts to avoid potential conflicts.

After documenting the allocation of bank-firm connections, we analyze if and how connections established through banks' governance relationships affect the borrowing practices of connected firms. To address this issue, we combine data on bank lending from the Loan Pricing Corporation with our data on board linkages among banks and non-financial firms. To 
test whether the potential for conflicts affects lending, we focus both on firm characteristics as well as a firm's likelihood of approaching financial distress, when the conflicts are most intense and where the potential trouble for the bank (and the public safety net) is the greatest. We find that connected banks, again, tend to provide credit to larger firms and tend not to lend to very risky firms, providing further support for the idea that the avoidance of potential conflicts plays the dominant role. We also find no evidence that banks lend on better terms to connected borrowers than to unconnected borrowers. Moreover, we find that connected banks provide a smaller fraction of loans to firms nearing financial distress. Thus, in contrast to the emerging economies, regulatory concerns that banks may lend based on favoritism to connected borrowers appear unjustified in the U.S.

The next section outlines the costs and benefits of board linkages between borrowers and lenders and explains how the potential conflicts arise and ways in which they may be mitigated. It also contains empirical implications of alternative hypotheses about connected lending. Section III describes the data, methods, and results. The final section provides a brief summary, implications of our results for regulatory policy, and directions for future research.

\section{Connections and Conflicts: The ory and Implications}

There are a number of benefits that a firm may enjoy by establishing a board connection with a bank. First, better information flow between the bank and the firm may allow the connected firm to borrow on better terms than would be possible from an unconnected bank.

Second, and more broadly, bankers are experienced at building relationships, gathering information for credit evaluation, and monitoring the evolution of credit relationships over time. 
These skill make bankers especially useful in the advisory responsibilities that come with serving as a corporate director. As we will show, banks tend to have more connections to other firms, both by having large boards with many outside directors, and by having more external directorships than other firms, consistent with the idea that these benefits are important.

Although a board linkage between a bank and a firm could reduce the costs of information flows between the lender and borrower, a board linkage also could generate conflicts of interest between the lender and borrower. While many different types of potential conflicts can arise from "connected" lending and borrowing, our primary focus here will be upon those conflicts that can lead to troubles for the bank. ${ }^{2}$ If the bank has a lending relationship with the firm, for example, an officer and director of the borrowing firm who is also a member of the bank's board can face a potential conflict of interest in terms of fiduciary duty as a director of both entities. In her role as director of the firm, the person will have a duty to obtain the best financing terms for the firm. As a member of the bank's board, however, the person has a duty to obtain the best terms for the bank and to avoid exposing the bank to undue risk. If the firm experiences a negative shock and financial distress, this potential conflict will intensify. The officer-director of the firm might display greater "loyalty" to her principal employer and put pressure on the bank to provide funding when other unconnected lenders would not and at terms favorable to the firm.

Similarly, a conflict can arise when an officer-director of the bank is a member of the

${ }^{2}$ See Kroszner and Strahan (forthcoming) for an analysis of other types of conflicts that can arise when a banker is on the board of a borrowing firm. See Kroszner and Rajan (1994 and 1997) for conflicts of interest in banking more generally. 
board of a firm borrowing from that bank. As a director of the borrowing firm, the person might feel pressure to help to obtain favorable lending terms for the firm. ${ }^{3}$ When the firm experiences financial distress, the pressure is likely to intensify. It is also possible that the firm might offer implicit or explicit compensation, perhaps in terms of stock options, to provide incentives for favorable treatment to the banker-as-director. As noted in the introduction, a number of studies of connected lending in countries outside of the U.S. have found evidence that connected lending has proved harmful to banks.

Our empirical strategy is designed to determine how the tradeoff between the benefit of better information versus the cost of potential conflicts associated with a bank connection is resolved in the U.S. One possibility is that the information benefits outweigh the costs of potential conflicts. Better information flow may thus support more efficient lending to the firm. Alternatively, directors may be relatively free to exploit the private information and control that comes with a board seat, perhaps because the legal, regulatory and corporate governance systems are insufficiently well-developed to punish misdeeds. Under either alternative, we would expect bank-firm board connections to be more common at firms that are difficult for outsiders to value and monitor. This implication follows because the ability to exploit information stemming from a connection would likely be curtailed by the actions of outside shareholders at firms where information is relatively transparent. If directors exploit their private information to the detriment of bank shareholders, we would also see firms receive favorable treatment from their

\footnotetext{
${ }^{3}$ In contrast, in Germany, banks have been accused of using their membership on firm's supervisory boards to manipulate the firm's borrowing for the bank's benefit (see Perltiz and Seger 1994 but contrary evidence from Chirinko and Elston 1998).
} 
connected bank, and such favoritism would be most pronounced when the firm experiences distress.

A second hypothesis is that the legal and regulatory regime deals with the potential for conflicts by creating large costs to directors associated with exploiting (or appearing to exploit) inside information or their ability to control management (see Kroszner and Rajan 1994 and 1997). Thus, concerns about the possibility of conflicts could raise the effective cost to the bank of lending to a connected firm enough to outweigh the benefits of improved information. If a connected loan does turn bad, for example, it might be difficult for the connected lender to explain to shareholders, "unconnected" managers or regulators that the initial transaction was undertaken at arm's length, even if it actually was. Internal controls or shareholder pressure may lead directors from distressed firms to leave a lending bank's board. ${ }^{4}$

Explicit aspect of U.S. bankruptcy doctrine create incentives for banks to avoid potential conflicts. Connected banks, for example, face the possibility of "lender liability" and "equitable subordination" lawsuits if the distressed firm goes into bankruptcy (see Smith and Warner 1979, Fischel 1989, Berlin and Mester 1999, and Kroszner and Strahan forthcoming). If a bank is found to have been active in firm management and acted "inequitably" prior to a borrower's bankruptcy, however, the bank can lose seniority in its claims against the bankrupt firm. In addition, a bank actively involved in firm management potentially faces liability for losses to other claimants that can be attributed to its actions. The courts can and sometimes do go further

${ }^{4}$ J.P. Morgan and Chase had arranged a large (\$7 billion) credit line from a bank syndicate for Xerox in 1997. After falling into distress in the subsequent years, Xerox drew down $\$ 5$ billion of the credit line in October 2000 amid speculation that it was on the edge of bankruptcy. At both the time of 
to assess punitive damages in lender liability cases. Board representation by the bank subjects the bank to "heightened scrutiny" in these actions, since the board connection facilitates the case that the bank had either inside information about or control over the distressed firm.

Regulatory scrutiny might also lead banks to avoid the temptation to lend to connected firms when the potential for conflicts is high (e.g. when the firm is likely to experience distress). Although executives do not face any direct legal restrictions on board relationships between banks and non-financial firms, Federal Reserve Board's Regulation O requires that the banks disclose to the regulators their executives' board memberships. Moreover, Regulation O stipulates that banks may not extend credit to any of its executive officers, directors, or principal shareholders, or to any of their "related interest," on preferential terms.

According to this idea, banks will tend to avoid exposing themselves to the costs of the conflicts by establishing connections only with firms that are transparent or that have a relatively low likelihood of generating potential conflicts. Thus, firms traditionally viewed as "bank dependent" -- small, risky firms and firms with high levels of intangible assets - will be least likely to have established a link to a bank, either by having a banker serve on its own board or by having one of its executives serve on a bank's board. Within the set of firms that have connections, those that are most likely to generate conflicts will again be least likely to borrower from the connected bank and, when they do borrow, the terms of connected loans will be similar to loans made to unconnected borrowers. Moreover, since the potential for conflicts would be heightened in financial distress, firms experiencing financial weakness will, again, tend not to

the origination and of the draw down, the CEO of Xerox, Paul Allaire, was a member of J.P. Morgan's board. Allaire was not nominated to serve on the board of Morgan/Chase in 2001. 
borrow from the connected bank. ${ }^{5}$

\section{Empirical Methods and Results}

In this section, we first provide a descriptive analysis of the scope of bank-firm connections through the board of directors (sub-section A). As we show, bankers (and hence banks) are substantially more connected to the corporate governance network than are executives from non-financial firms. Next, we describe the allocation of bank connections across nonfinancial firms as a function of characteristics related to information asymmetry and the potential for conflicts. Third, we investigate how the quantity and pricing of bank loans varies with the same set of firm characteristics used to describe the allocation of connections. The last two subsections (B and C) contain the key tests of the ideas described in above. Note that we first consider any board connection between a bank and a non-financial firm, and then we separate the connections into two types, those in which bankers serve as directors on non- financial firms' boards, and those in which executives from non-financial firms serve on banks' boards.

\section{A. Financial and Non-financial Firms' Boards and External Directorships}

We build our sample of board connections from information reported in the 1992 Forbes 500 lists for financial and non-financial firms supplied to us by Kevin Hallock (1997 and 1999). Forbes classifies the largest 500 firms by four criteria: sales, profits, assets, and market value in 1992. Based on these four criteria, there are 708 firms for which we have complete board information. For each firm, Hallock collected the names and principal employers of each

\footnotetext{
${ }^{5}$ See Cantillo and Wright (2000) on evidence of how firms choose their lenders and Gorton and
} 
director. If a person is on the board of the firm that is also her principal employer, we define that person as an employee-director or "inside director." These data then allows us to determine the board linkages between banks and non-financial firms. We identify both bank executives (bank inside directors) who are on the boards of non-financial firms as well as non-financial firm executives (non-financial inside directors) who are on the boards of commercial banks. When an executive has a seat on the board of a firm in the sample that is not her principal employer, we call that relationship an "external board membership" or "external directorship."

Table 1 provides the mean, median, and standard deviation for a variety of board characteristics of financial and non-financial firms in the Forbes lists in 1992. We classify financial firms as commercial banks $(n=121)$, insurance companies $(n=57)$, and other financials ${ }^{6}$ $(n=17)$. We have 513 non-financials. This gives us a total of 708 firms. In our sample, the boards of commercial banks tend to be larger than the boards of non-financial firms. Commercial banks' boards have a mean of 16 members versus 12 for non-financials. Both the commercial banks and the non-financials have roughly three inside directors on the board, so the fraction of inside directors is lower at banks than at non-financials. The boards of insurance companies and other financials in the sample appear to look more like the boards of nonfinancials than commercial banks. In these raw comparisons, the commercial bank board members appear to have fewer external board connects than do the non-financial firms.

These simple comparisons, however, do not adjust for the size of the firm or the bank, and firm size is strongly correlated with board size. The banks in the Forbes top financial lists

Kahn (2000) for a theoretical discussion of the design of bank loan contracts. 
appear very large based on a size-ranking using total assets. Citicorp, for example, appears larger than General Motors based on total assets - $\$ 213$ billion versus $\$ 191$ billion; however, GM has almost ten times as many employees as Citicorp - 750,000 versus 81,000 . Thus, the raw comparisons tend to generate a bias toward non-financial firms, since, as we show, larger firms tend to have larger boards and more external directorships.

In Table 2, we adjust for the size of the enterprise. For each board characteristic, Panel A contains two OLS specifications. The first column contains only an indicator for whether the enterprise is a commercial bank and the log of market capitalization. We are able to find 680 firms with non-missing data on Compustat in 1992. The second column includes those variables plus indicators for whether the enterprise is an insurance company and whether it is "other" financial. The log of the number of employees is also included as an additional control for size in this second specification. We find employment data for 591 firms on Compustat.

As Table 2 demonstrates, controlling for size, commercial banks have larger boards with more outside directors and a smaller proportion of inside directors than do non-financial firms. The bank indicator variable is highly statistically significant in each of these regressions. While the raw comparisons suggest that banks have a little more than 4 more outside directors than non-financials, the regression suggests that a bank has more than 5 additional outside directors than a non-financial firm of similar size. The indicator is small and not statistically significant in explaining the number of inside directors. Thus, controlling for size, we also find no difference in the number of insiders for financials and non-financials. The final two columns of Table 2

\footnotetext{
${ }^{6}$ Investment banks and investment management firms comprise most of the 'other' category.
} 
have the number of external directorships as the dependent variable. Here we find that once we control for size, banks have a larger number of outside directorships than do non-financial firms.

Panel B reruns the same specifications as in Panel A but uses a Poisson regression technique since the board characteristics are count variables. The one exception is the share of inside directors, which varies between 0 and 1 . To adjust for that, Panel B reruns the Panel A regressions using the logistic transformation of insider share, that is, log [insider share/(1-insider share)]. The results in Panel B are very similar in terms of signs and statistical significance so confirm the OLS results in Panel A.

Large commercial banks thus appear to be more heavily involved in the corporate governance network than are large non-financial firms. They tend to have big boards due to the large number of outside directors, thereby establishing more connections to other firms than do non-financials. In addition, the officer-directors (inside directors) of the banks tend to have more external directorships, so they tend to have more external board connections than do their counterparts at non-financial firms. These results are consistent with banks specializing in the business of building relationships, gathering information, and monitoring (e.g., Diamond 1984). ${ }^{7}$

\section{B. The Allocation of Bank Board Connections ${ }^{8}$}

${ }^{7}$ One possibility that could explain why commercial banks are so actively involved in the corporate governance network is that bankers enjoy the prestige and enhancement of their reputation that comes with a board seat. One would have to argue, however, that bankers demand prestigious board seats more than executives from other financial services firms (e.g. securities firms or insurance companies) and more than executives of non-financial corporations.

${ }^{8}$ There is a large and generally inconclusive literature trying to test whether various compositions of the board dominate others (e.g. large vs. small boards, insider- vs. outsider-controlled boards). Rather than address these issues, our purpose is to try to understand the forces that shape the structure of the board. (See, e.g., Agrawal and Knoeber, 1996; Baysinger and Butler, 1985; Bhagat and Black, 1997, 
In Section II we outlined the tradeoff between the information benefit of bank links versus the costs of potential conflicts. That discussion suggests that the efficiency with which the legal and regulatory environment constrain managers' and directors' potential use of private information for personal gain will affect which firms have link to banks, as well as the actions taken by those firms that do have connections to banks. On the one hand, if directors are able to exploit their information and control over the firm, then we would expect to see more connections at firms where such exploitation would be most valuable; that is, at the traditionally bank dependent firms or firms with significant asymmetric information. On the other hand, if the potential costs of exploiting conflicts are sufficiently high, we would expect just the opposite: bank connections would be most prevalent at firms where the potential for conflicts are the lowest; that is, at firms with relatively low levels of asymmetric information.

To test these ideas, we obtain characteristics for our sample of firms from the 1992 Compustat. In our analysis of the relationship between firm characteristics and bank connections, we start with the 708 firms from the Forbes 500 lists. We then drop all of the financial institutions and those firms for which firm characteristics from Compustat and returns from the Center for Research in Securities Prices (CRSP) are not available. The resulting sample includes a total of 430 firms. Of these, 230 are connected to a bank via the board of directors; 75 have one or more bankers on their boards, 94 have an executive that serves on a bank's board, and 61 have both.

We focus on six firm characteristic related to information and control problems. First, we

1998; Booth and Deli, 1998; Brickley, Lease, and Smith,1988; Gertner and Kaplan, 1997; Hermalin and Weisbach, 1988; Klein, 1998; Kracaw and Zenner, 1998; Payne, Millar, and Glezen, 1996; Rosenstein 
include the log of total assets (book value) as a measure of firm size. The potential conflict of interest costs are likely to be higher at small firms because small firms are more likely to use bank loans for credit, because they are more likely to experience financial distress, and because they tend to be younger and less well-known and, hence, more difficult for outsiders to value. Larger firms tend to have larger boards than smaller firms, however, giving them more opportunities to have an outsider director such as a banker. Therefore, size also acts as a control variable in the models. ${ }^{9}$

Second, we include the volatility of the firm's equity, which should be related to the extent of the asymmetric information problem the firm faces in trying to obtain external finance. Our measure of volatility is the standard deviation of monthly equity returns, measured from January 1988 to December 1991. Since conflicts of interest between shareholders and creditors increase with the riskiness of a firm's investment opportunities, efforts to avoid such conflicts could lead to fewer bank connections at very risky firms. The benefits of bank connections, however, also likely increase with firm volatility. So, we report specifications with both volatility and its square to allow the relationship between risk, bank connections and connected lending to first increase, and then decrease.

Third, we include a direct measure of a firm's likelihood of facing financial distress. Distress increases both the degree of asymmetric information for firms, and the degree of conflicts between creditors and shareholders and between different classes of creditors. Our

and Wyatt, 1990; Weisbach, 1988; Yermack, 1996).

${ }^{9}$ Kroszner and Strahan (forthcoming) show that board size can not explain the link between firm characteristics such as size and the presence of a banker on the board. 
measure is based on the interest coverage ratio (see Andrade and Kaplan, 1998). The interest coverage ratio equals annual gross cash flow divided by total interest expenses. Gross cash flow equals earnings before interest, taxes, and depreciation (EBITDA). We use a financial distress indicator variable equal to one for a firm if its interest coverage ratio falls in the lowest decile of interest coverage ratio distribution; in our sample, this means that the interest coverage ratio falls below two.

Fourth, firms with more intangible assets are likely to be more opaque and therefore create greater information asymmetry problems than firms with more tangible assets. Costs of financial distress and the potential for "manipulation" are also more likely at firms with high levels of intangibles that may be difficult or impossible to liquidate. We measure tangibility of assets as the ratio of net property, plant, and equipment to total assets.

Fifth, we include a commercial paper rating indicator variable as a direct measure of a firm's access to credit from securities markets. Since commercial paper issuers have access to a close substitute for bank loans, they will tend to depend less on banks and thus will have a lower likelihood of creating conflicts for the connected banker.

Finally, we include leverage and short-term debt in some of our specifications as measures of the firm's capital structure. Greater leverage likely increases the potential for conflicts between the banker and the shareholder of the borrowing firm. Our measure of leverage is the ratio of the book value of total debt, including long and short-term debt, to the market value of equity plus the book value of total debt. We also include the fraction of total debt that is short-term debt, defined as debt with maturity under one year. Much of this debt will consist of bank credit or close substitutes for it, and thus can be interpreted as a proxy for the 
value of a bank relationship to the firm. ${ }^{10}$

Table 3 reports the median characteristics of firms with and without bank connections. Column 1 contains medians for the 230 connected firms, and column 5 contains medians for the 200 unconnected firms. Connected firms tend to be larger and more stable than unconnected firms. The connected firms also have a higher fraction of tangible assets to total assets, helping to increase their capacity to issue public debt, and they are more likely to hold a commercial paper rating and have higher leverage. ${ }^{11}$ This higher leverage of the connected firms is revealed by their somewhat lower interest coverage ratio. ${ }^{12}$

Table 4 contains the results of a probit model designed to relate firm characteristics to the presence of a connection in a multivariate context. The dependent variable is one if the firm has a banker on its own board or if the firm has an executive serving on a bank's board; otherwise, the dependent variables equals zero. The table reports the marginal effects, rather than the probit coefficients themselves, which measure the change in the probability of a firm having a bank connection from the mean of the independent variable. The results support the idea that bank

${ }^{10}$ Firm size is correlated with a number of the other variables included in the analysis. In our sample, the correlation coefficient between size and leverage is 0.42 ; the correlation between size and the commercial paper indicator is 0.34 ; and the correlation between size and volatility is -0.34 . Firm size and the other variables could therefore be serving as proxies for similar factors. Note also that the correlation between the commercial paper indicator and volatility is -0.31 .

${ }^{11}$ Connected firms also have a higher market-to-book ratio, another measure of the importance of intangible assets, than unconnected firms. The connected firms' median market-to-book asset ratio equals 1.5 , compared to 1.3 for the unconnected firms. This difference is statistically significant at the one percent level. In our regressions, we prefer to use the ratio of property, plant and equipment to total assets to measure asset tangibility since this variable, in contrast to the market-to-book ratio, does not have large outliers.

12 The connected firms also have lower ratios of cash and liquid assets to total assets, but they pay 
connections reflect the avoidance of potential conflicts. Specifically, connections are more likely at larger and more stable firms, at firms with higher ratios of tangible to total assets, and at firms with a commercial paper ratings. Although not statistically significant, the coefficients on both leverage and short-term debt are also negative, so there is no evidence that connections are more prevalent at firms with high leverage or a high degree of dependence on bank debt. Similarly, there is no evidence that bank connections are more common at firms nearing financial distress. ${ }^{13}$

The magnitudes of the effects are also economically important. In the linear specification (column 1), for example, a one standard deviation increase in our volatility measure decreases the probability of having a bank connection by roughly 13 percentage points. A one standard deviation increase in the log of assets raises the probability of having a bank connection by 12 percentage points. In column (3), a one standard deviation increase in the tangible asset ratio increases the likelihood of having a banker on the board by 8 percentage points, and firms with a commercial paper rating are about 14 percent more likely to have a bank connection.

Since the probit is a non-linear model, comparing two firms at opposite ends of the "asymmetric information spectrum" provides somewhat more realism than looking at the effects of varying characteristics individually. For example, the model predicts that a firm in the upper $25^{\text {th }}$ percentile of the size and tangible asset distribution, with high cash flow, a commercial paper rating, and low stock return volatility (bottom $25^{\text {th }}$ percentile) has a 77 percent chance of having a bank connection. In contrast, a firm in the lower $25^{\text {th }}$ percentile of the size and tangible

out a higher fraction of their net income as dividends. The connected firms, thus, do not appear to be more cash constrained or more bank dependent than the unconnected firms.

${ }^{13}$ In contrast, Kaplan and Minton (1994) find that Japanese bankers are more likely to join the 
asset distribution, with low cash flow, no commercial paper rating, and high stock return volatility (upper $25^{\text {th }}$ percentile) has just a 38 percent chance of having a bank connection. (The unconditional probability equals 54 percent.)

To understand better whether connections from the bank to the firm's board reflect different characteristics than connections from the firm to the bank's board, we also separate the connections into three parts: connections in which a banker serves on the firm's board, connections in which a firm executive serves on a bank's board, and connections in which a firm has both a banker on its board and an executive on a bank's board. Looking first at the univariate comparisons in Table 3, we see that all three groups of connected firms are generally larger, safer, and less opaque than the comparison group of firms without board connections to banks. All three groups of connected firms have more tangible assets and they are more likely to hold a commercial paper rating than the unconnected firms. Thus, the univariate comparisons suggest that efforts to avoid potential conflicts help explain the allocation of all three kinds of connections.

We analyze these relationship formally in a multivariate context using a multinomial logit regression (Table 5). In this model, the coefficients measure how the probability of a firm having one of the three kinds of connections varies with changes in the explanatory variable, relative to the reference category of having no bank connection. The results generally support the idea, again, that efforts to avoid bank connections where potential conflicts are more likely to emerge drive the results. The coefficients for each of the three connections are jointly statistically significant. Large and stable firms are more likely to have bank connections of all

boards of borrowing firms when those firms experience financial diffic ulties. 
three kinds, and firms with more tangible assets and a commercial paper rating are also more likely to have a connection. The statistical significance of the size and ratings effect, however, is low in the group of firms with just a banker on their own board (column 1). ${ }^{14}$

The results in Table 5 also suggest a non-linear relationship between risk and the probability that a firm has connections both to a bank's board and from a bank executive to its own board (column 3). (In the first two columns, the relationship is negative.) In column 3, the linear term is positive and the squared term is negative and the two terms are statistically significant individually and jointly. The probability that a firm has a two-way bank connection increases up to volatility of about 0.07 (slightly below the median of 0.077 ), then decreases. Thus, when volatility is low, the benefits of having a very close link to a bank increase faster than the costs, but when volatility rises above the sample median, the potential costs from conflicts dominate the allocation of the bank board connections

\section{Connections and Bank Borrowing}

Having established that board links between banks and non-financial firms are important quantitatively, and that these connections are more common at the low information-cost firms, we now investigate how such linkages affect borrowing behavior. If conflict avoidance affects borrowing behavior in the same way that it affects the allocation of connections, then we ought to observe that connected firms that actually borrow from their connected bank do so on fair

\footnotetext{
${ }^{14}$ Firms with connections both ways sometimes reflect interlocked boards. Out of the 61 firms with connections both ways, 22 are from bank-firm pairs with interlocked boards. We have also estimated a multinomial logit model that allows an additional state for the 22 bank-firm pairs with interlock boards. However, the coefficients determining the probability of having an interlocked board with a bank are not statistically significantly different from the coefficients determining the probability of having connections to and from a bank's board.
} 
terms; that is, on the same terms that they would face when borrowing from an unconnected bank. Also, we ought to observe that within the set of connected firms, those that actually borrow from connected banks pose the lowest likelihood of generating conflicts. Thus, we test first how the share of loans from connected banks varies with firm characteristics, and second whether the interest rate on loans to connected firms is lower when they borrow from a connected bank than when they borrow from an unconnected bank. For both tests, we focus only on those firms with board connections to banks.

To investigate borrowing, we use the Dealscan database compiled by the Loan Pricing Corporation (LPC). Dealscan provides detailed coverage of bank lending to large corporations from 1988 to the present (see Strahan 1999). These data allow us to identify which banks are lending to which firms in each year. We match our data on board connections in 1992 to loans made to the connected firms between 1992 and 1994. The LPC data also provide details on the characteristics of loans, such as interest rates, fees, maturity, amount, security, whether the loan involves a revolving credit agreement, and the stated purpose of the loan.

Most loans to the large firms in our sample are syndicated, meaning that more than one bank provides funding. Dealscan provides information about each bank's role in the syndicate (e.g. lead arranger, participant, etc.). For each loan, we determine whether the connected bank acted as the lead arranger in the syndicate. The lead bank is responsible for assembling the syndicate and arranging the financing terms of the loans. In return, this bank receives a management fee. In most cases, the lead bank holds the largest share of the loan, whereas participant banks generally hold smaller shares. For example, for syndicates with at least five lenders, the average share held by the lead arranger equals 16 percent, compared to only 6 
percent for participant banks.

\section{Connections and the quantity of loans}

To test how the share of a firm's bank loans from connected banks varies with firm characteristics, we include all connected firms for which we can find the firm characteristics on Compustat and for which we can find one or more loans made between 1992 and 1994 on LPC's Dealscan. This leaves us with a total of 136 connected borrowers, out of a possible $230{ }^{15}$ For each of these firms, we model the share of loans for which the connected bank acts as the lead arranger as a function of the same set of borrower characteristics related to information asymmetry and the potential for conflicts (Table 6). We then dis-aggregate the dependent variable into the share of loans in which the lead bank is connected by having an executive serve on the firm's board, and the share of loans in which one of the borrowers's executives serves on the lead bank's board (Table 7).

In Table 6, we find that a similar set of relationships that described the allocation of bank connections across firms also describe the pattern of borrowing. In general terms, the low information-cost firms are more likely to borrow from their connected bank than the higher information-cost firms. Larger firms borrow substantially more from their connected bank than smaller firms; a one standard deviation increase in the log of firm assets, for example, is associated with an increase in borrowing from the connected bank of 8 to 10 percent. Perhaps even more striking, firms with interest coverage ratio in the lowest decile - that is, firms most likely to experience distress over the near term - borrow 14 to 22 percent less from their

\footnotetext{
${ }^{15}$ We lose two observations in the specification that includes capital structure due to missing data
} 
connected bank than other firms.

The effect of volatility is again non- linear. The linear specification (column 1) suggests that among the connected firms, those with higher risk tend to borrow more from their connected bank. This relationship increases only to the median level of volatility in the sample, however, and then flattens out. For example, increasing stock return volatility from the $10^{\text {th }}$ percentile (0.048) to the median (0.077) raises the share borrowed from the connected bank by 18 percent, whereas increasing the return volatility from the median to the $90^{\text {th }}$ percentile $(0.122)$ reduces the share by about 1 percent.

In Table 7, we report the same set of regressions after dis-aggregating the dependent variable into the share borrowed from the bank that serves on the firm's board, and the share that comes from the bank on whose board a borrower's executive serves. The disaggregation suggests that conflict avoidance plays an important role in borrowing from connected banks, regardless of how the board connection is established. The sign patterns for the variables are quite consistent across the two dependent variables, although the statistical significance is not always the same. For example, stock return volatility is more important in explaining variation in the share of loans coming from the bank that serves on the firm's board (columns 1 and 2), although the effect is non-linear. In the specification from column 1, increasing stock return volatility from the $10^{\text {th }}$ percentile $(0.048)$ to the median $(0.077)$ raises the share borrowed from the connected bank by 14 percent, while increasing the return volatility from the median to the $90^{\text {th }}$ percentile $(0.122)$ reduces the share borrowed by 10 percent.

In contrast, size and the low interest coverage ratio are more important in explaining

from Compustat. 
variation in the share borrowed from the bank on whose board the borrower's executive serves. In column (3), for example, the share of loans from the bank on whose board the borrower's executive serves is 24 percent lower for firms with coverage ratios in the bottom $10^{\text {th }}$ percentile of the distribution. Thus, firms that are relatively close to financial distress avoid borrowing from banks connected this way.

\section{$\underline{\text { Connections and loan pricing }}$}

The LPC Dealscan data provides sufficient detail on the characteristics of each loan to be able to calculate the "drawn all-in spread." The borrower pays the drawn all-in spread (AIS) to the lender each year for each dollar drawn off of a line of credit, or, in the case of a term loan, off the whole amount of the loan. The drawn AIS equals the coupon rate plus the annual fee, measured as a markup over LIBOR. ${ }^{16}$ The mean drawn AIS for all loans in Dealscan between 1992 and 1994 equals 206 basis points. In contrast, the mean drawn AIS equals only 61 basis points in our sample, reflecting the fact that the connected borrowers tend to be much larger and safer than average. For revolving lines of credit, the borrower also pays the undrawn AIS to the lender each year for every dollar of the line not drawn, equal to the commitment fee plus the annual fee. The mean undrawn AIS on all lines of credit in Dealscan between 1992 and 1994 equals 35 basis points. For our sample, the mean undrawn AIS equals 16 basis points.

The dependent variable is the drawn AIS for all loans made to our sample of 136 connected borrowers from whom we have both loan data and Compustat characteristics. All of

\footnotetext{
${ }^{16}$ While most loans are floating rate, some are priced off other benchmark interest rates. If a LIBOR spread is available, it is used. For cases where another benchmark is used, LPC makes the following adjustments to the drawn AIS: Prime $=+255$ bps; Cost of funds=0 bps; Commercial Paper=3
} 
the specifications include (but do not report the coefficient estimates of) the following loan characteristics: $\log$ of loan size, $\log$ of maturity, and indicators for lines of credit, secured loans (as well as an indicator if information about security is missing), and stated purpose of the loan. Since we have more than one loan for some or our borrowers, we account for possible heteroskedasticity by estimating the random-effects GLS model.

With the exception of firm size, in all specifications the firm-characteristics that increase risk and asymmetric information are associated with a higher drawn AIS (Table 8). Thus the bank loans seem to price characteristics likely to be associated with high levels of expected losses and risk. For instance, firms with higher stock return volatility, firms with low interest coverage ratio and high leverage, and firms without commercial paper ratings pay higher interest rates than other firm. While the log of firm assets enters positively, the effect of size becomes negative and statistically significant when loan size is dropped from the regression (coefficient not reported).

Most important for our purposes, the results suggest that banks do not favor their connected borrowers. If banks extend credit to connected borrowers on terms not justifiable on economic grounds, then we should observe lower interest rates under these circumstances. ${ }^{17}$ The coefficient on the indicator for the presence of a board link to the lender, however, is never negative and statistically significant in Table 8 . We have also estimated (but do not report) similar models that use the other dimension of pricing (the undrawn all-in spread) and two nonbps; T-bills=-34 bps; Fed Funds=0 bps; Money market rate=0 bps; Banker's acceptance $=-18$ bps; CDS=6 bps.

${ }^{17}$ Another possibility (which we do not observe) would be that connected borrowers receive credit 
price terms, the log of average maturity and an indicator for whether or not the loan is secured, as dependent variables. Consistent with the results reported on loan spreads, we find that firms borrowing from their connected bank do not pay lower fees, and they do not receive more generous non-price terms than firms borrowing from unconnected banks. Thus, there is no empirical evidence that banks extend favoritism to their borrowers connected through a board linkage.

\section{Conclusions}

We have examined the extent of U.S. commercial bank involvement in the corporate governance network and the implications of bank board linkages for lending and borrowing behavior. Commercial banks' boards tend to be larger and have a greater proportion of outside directors than do non-financial firms. Bank executives also tend to have a high number of external board positions relative to non-financial executives (see also Kroszner and Strahan forthcoming).

Such board links could affect lending and borrowing by improving the information flow between the linked banks and firms, but these links could also generate conflicts of interest that could lead banks to "throw good money after bad" if a connected borrower falls into financial distress. Contrary to studies of connected lending in Mexico, Russia, and Asia crisis countries, we find no evidence in the U.S. that connected lending exposes banks to undue risk or that they succumb to conflicts of interest. On the contrary, the allocation of board connections here in the U.S. suggests that efforts to avoid conflicts plays a dominant role. Large, safe firms with high

on better terms because their bank can generate information more cheaply than an unconnected bank. 
levels of tangible assets appear more likely to have connections to banks, precisely the kinds of firms least likely to generate the potential for conflicts, both because these firms are relatively unlikely to experience financial distress, and because these firms present the relatively few opportunities for directors to have private information.

We also find that actions taken after connections have been established seem to reflect efforts to avoid conflicts. Connected banks tend to lend to those firms that are larger and less likely to experience financial distress. In contrast, bankers in Japan appear to take a more active role in governing firms that become distressed. Moreover, we find no evidence that banks lend to their connected borrowers on terms other than what would be expected from an arm's length lender.

Our results suggest that the U.S. regulatory and legal environment perhaps deal better with potential conflicts associated with insiders and directors than has been found in countries such as Mexico and Russia. Rather than succumb to conflicts, U.S. bankers avoid them. The Gramm-Leach-Bliley Financial Modernization Act of 1999, however, opens new possibilities for commercial banks to own equity in non-financial firms which can help to mitigate divergent interests between a bank and firms that borrow from it. Thus, in contrast to the past, U.S. bankers may become increasingly willing to establish connections at smaller and riskier firms where those connections would be most valuable. 


\section{References}

Agrawal, A., Knoeber, C., 1996. Firm performance and mechanisms to control agency problems between managers and shareholders. Journal of Financial and Quantitative Analysis 31, 377-397.

Andrade, Gregor and Steven N. Kaplan, 1998, "How Costly Is Financial (Not Economic) Distress? Evidence from Highly Leveraged Transactions That Became Distressed," Journal of Finance, v53, n5 (October), 1443-93.

Baysinger, B., Butler, H., 1985. Corporate governance and the board of directors: performance effects of changes in board composition. Journal of Law, Economics, and Organization 1, 101124.

Bhagat, S., Black, B., 1997. Do independent directors matter? Unpublished working paper. Columbia Law School, New York,

Bhagat, S., Black, B., 1998. The uncertain relationship between board composition and firm performance. In: Hopt, K., Roe, M., Wymeersch, E. (Eds.), Corporate Governance: The State of the Art and Emerging Research. Oxford University Press, Oxford, England.

Booth, J., Deli, D., 1998. On executives of financial institutions as outside directors. Unpublished working paper, Arizona State University, Tucson.

Brickley, J., Lease, R., Smith, Jr., C., 1988. Ownership structure and voting on antitakeover amendments. Journal of Financial Economics 20, 267-292.

Cantillo, Miguel, and Julian Wright, 2000, "How Do Firms Choose their Lenders? An Empirical Investigation," Review of Financial Studies, 13:1 (Spring), 155-89.

Chirinko, R., Elston, J., 1998. Finance, control, and profitability: an evaluation of German bank influence. Unpublished working paper, Emory University.

Diamond, D., 1984. Financial intermediation and delegated monitoring. Review of Economics Studies 51, 393-414.

Fischel, D., 1989. The economics of lender liability. Yale Law Journal 99, 131-154.

Gertner, R., Kaplan, S., 1997. The value maximizing board of directors. Unpublished working paper. University of Chicago.

Hallock, Kevin F., 1997, "Reciprocally Interlocking Boards of Directors and Executive 
Compensation," Journal of Financial and Quantitative Analysis, 32(3), September.

Hallock, K., 1999. Dual agency: corporate boards with reciprocally interlocking relationships. In: Carpenter, J., Yermack, D. (Eds.), Executive Compensation and Shareholder Value: Theory and Evidence.

Hermalin, B., Weisbach, M., 1988. The determinants of board composition. Rand Journal of Economics 19, 589-606.

Hoshi, Takeo, Anil Kashyap, and David Scharfstein, 1991, "Corporate Structure Liquidity and Investment: Evidence from Japanese Panel Data," Quarterly Journal of Economics, 33-60.

Hoshi, T., Kashyap, A., Scharfstein, D., 1993. The choice between public and private debt: an analysis of post-deregulation corporate financing in Japan. NBER Working Paper No. 4421, Cambridge, MA.

Klein, A., 1998. Affiliated directors: puppets of management or effective directors? Unpublished working paper. Stern School of Business, New York University.

Kracaw, W., Zenner, M., 1998. Bankers in the boardroom: good news or bad news? Unpublished working paper. Kenan-Flagler Business School, University of North Carolina.

Gorton, Gary and James Kahn, 2000, "The Design of Bank Loan Contracts," Review of Financial Studies, 13:2 (Summer), 331-64.

Kaplan, S., Minton, B., 1994. Appointments of outsiders to Japanese boards: determinants and implications for managers. Journal of Financial Economics 36, 225-258.

Kashyap, Anil, Jeremy Stein, and David Wilcox, 1993, "Monetary Policy and Credit Conditions: Evidence from the Composition of External Finance," American Economic Review 83:1 (March), 78-98.

Kroszner, Randall S. and Raghuram G. Rajan, 1994. Is the Glass-Steagall Act justified? A study of the United States experience with universal banking before 1933. American Economic Review 84 (September), 810-32.

Kroszner, Randall S. and Raghuram G. Rajan, 1997. Organization structure and credibility: Evidence from commercial bank securities activities before the Glass-Steagall Act. Journal of Monetary Economics 39 (August), 475-516.

Kroszner, Randall S. and Philip E. Strahan, 1996. Regulatory incentives and the Thrift Crisis: Dividends, mutualto-stock conversions, and financial distress. Journal of Finance 51 (September), 1285-1320. 
Kroszner, Randall S., and Philip E. Strahan, forthcoming, "Bankers on Boards: Monitoring, Conflicts of Interest and Lender Liability," Journal of Financial Economics.

Laeven, Luc, 2001, "Insider Lending and Bank Ownership: The Case of Russia,” World Bank Group, working paper.

Lamoreaux, Naomi, 1994, Insider lending: Banks, personal connections, and economic development in industrial New England, New York: Cambridge University Press.

La Porta, Raphael, Florencio Lopez-de-Silanes, and Zamarripa, 2001, "Insider Lending in Mexico," unpublished working paper, Harvard University.

Mizruchi, Mark S., 1996, "What Do Interlocks Do? An Analysis, Critique, and Assessment of Research on Interlocking Directorates," Annual Review of Sociology, 22, 271-98.

Payne, T., Millar J., Glezen G.W., 1996. Fiduciary responsibility and bank-firm relationships: an analysis of shareholder voting by banks. Journal of Corporate Governance 3, 75-87.

Perlitz, Manfred, and Seger, Frank, 1994. Regarding the particular role of universal banks in German corporate governance. Working paper, University of Mannheim.

Petersen, Mitchell and Raghuram Rajan, 1994. The benefits of lending relationships: Evidence from small business data, Journal of Finance 49, 3-37.

Rajan, Raghuram and Luigi Zingales, 1998, "Which Capitalism? Lessons from East Asian Crisis," Journal of Applied Corporate Finance, 11(3), Fall, 40-48.

Rosenstein, S. and Wyatt J., 1990. Outside directors, board independence, and shareholder wealth. Journal of Financial Economics 26, 175-191.

Smith, Clifford and Jerold Warner, 1979. On financial contracting: An analysis of bond covenants. Journal of Financial Economics 7 (June), 117-161.

Strahan, Philip E., 1999. Borrower risk and the price and nonprice terms of bank loans. Federal Reserve Bank of New York, Staff Report no. 90 (October).

Weisbach, M., 1988. Outside directors and CEO turnover. Journal of Financial Economics 20, 431-460.

Yermack, D., 1996. Higher market valuation of companies with a small board of directors. Journal of Financial Economics 40, 185-213. 


\begin{tabular}{|c|c|c|c|c|}
\hline \multicolumn{5}{|c|}{$\begin{array}{c}\text { Table } 1 \\
\text { Board Size, Board Composition, and External Directorships of Officer-Directors for } \\
\text { Financial and Non-Financial Firms: Mean, Median, and Standard Deviation }\end{array}$} \\
\hline \multicolumn{5}{|c|}{$\begin{array}{l}\text { This table reports board characteristics for Forbes } 500 \text { listings of publicly-traded financials and } \\
\text { non- financials in } 1992 \text { (see Hallock 1997). The financial firms are classified as commercial } \\
\text { banks, insurance companies, and other financials. Each cell contains the mean on the first line, } \\
\text { the median in square brackets on the second line, and the standard deviation in parentheses on } \\
\text { the third line. Officer-directors or "inside" directors are members of a firm's board whose } \\
\text { principal employer is that firm. Non-employee or "outside" directors are members of a firm's } \\
\text { board whose principal employer is not that firm. External board memberships are the number } \\
\text { of directorships on other Forbes } 500 \text { firms held by the inside directors of a firm. }\end{array}$} \\
\hline & $\begin{array}{l}\text { Non- } \\
\text { Financials }\end{array}$ & $\begin{array}{l}\text { Commercial } \\
\text { Banks }\end{array}$ & $\begin{array}{l}\text { Insurance } \\
\text { Companies }\end{array}$ & $\begin{array}{c}\text { Other } \\
\text { Financials }\end{array}$ \\
\hline Size of Board & $\begin{array}{l}11.86 \\
{[12]} \\
(3.00)\end{array}$ & $\begin{array}{l}16.01 \\
{[15]} \\
(6.01)\end{array}$ & $\begin{array}{l}11.40 \\
{[11]} \\
(3.95)\end{array}$ & $\begin{array}{l}12.59 \\
{[12]} \\
(5.51)\end{array}$ \\
\hline $\begin{array}{l}\text { Number of Non-employee } \\
\text { Directors ("Outsiders") }\end{array}$ & $\begin{array}{l}8.70 \\
{[9]} \\
(2.70)\end{array}$ & $\begin{array}{l}12.98 \\
{[12]} \\
(5.79)\end{array}$ & $\begin{array}{c}8.58 \\
{[9]} \\
(3.37)\end{array}$ & $\begin{array}{c}8.06 \\
{[7]} \\
(3.27)\end{array}$ \\
\hline $\begin{array}{l}\text { Number of Officer- } \\
\text { Directors ("Insiders") }\end{array}$ & $\begin{array}{c}3.16 \\
{[3]} \\
(2.92)\end{array}$ & $\begin{array}{c}3.04 \\
{[3]} \\
(1.70)\end{array}$ & $\begin{array}{c}2.82 \\
{[2]} \\
(1.80)\end{array}$ & $\begin{array}{c}4.53 \\
{[3]} \\
(5.06)\end{array}$ \\
\hline $\begin{array}{l}\text { Fraction of Officer- } \\
\text { Directors ("Insiders") on } \\
\text { the Board }\end{array}$ & $\begin{array}{l}0.27 \\
{[0.25]} \\
(0.13)\end{array}$ & $\begin{array}{c}0.20 \\
{[0.18]} \\
(0.11)\end{array}$ & $\begin{array}{l}0.26 \\
{[0.22]} \\
(0.16)\end{array}$ & $\begin{array}{l}0.33 \\
{[0.25]} \\
(0.18)\end{array}$ \\
\hline $\begin{array}{l}\text { Number of External Board } \\
\text { Memberships of the } \\
\text { Officer-Directors } \\
\text { ("Insiders") }\end{array}$ & $\begin{array}{c}1.97 \\
{[1]} \\
(2.92)\end{array}$ & $\begin{array}{c}1.16 \\
{[0]} \\
(2.32)\end{array}$ & $\begin{array}{c}0.84 \\
{[0]} \\
(1.29)\end{array}$ & $\begin{array}{c}1.94 \\
{[1]} \\
(1.94)\end{array}$ \\
\hline Number of Firms & 513 & 121 & 57 & 17 \\
\hline
\end{tabular}


Table 2

Estimates relating Board Size, Board Composition, and External Directorships of Officer-Directors (Insiders) for Financial and Non-Financial Firms in 1992

Panel A: OLS

The table contains OLS estimates of the differences in board characteristics between financial and non-financial firms, controlling for firm size. Financial firms are classified as commercial banks, insurance companies, and other financials. The dependent variables are listed over each pair of columns. Officer-directors or "inside" directors are members of a firm's board whose principal employer is that firm. Non-employee or "outside" directors are members of a firm's board whose principal employer is not that firm. External board memberships are the number of directorships on other Forbes 500 firms held by the inside directors of a firm. Standard errors are in parentheses. The sample is drawn from Forbes 500 listings in 1992 (see Hallock 1997).

\begin{tabular}{|c|c|c|c|c|c|c|c|c|c|c|}
\hline \multirow[t]{2}{*}{$\begin{array}{l}\text { Dependent } \\
\text { Variable: }\end{array}$} & \multicolumn{2}{|c|}{ Board Size } & \multicolumn{2}{|c|}{$\frac{\text { Number of Outside }}{\text { Directors }}$} & \multicolumn{2}{|c|}{$\frac{\text { Number of Inside }}{\underline{\text { Directors }}}$} & \multicolumn{2}{|c|}{$\frac{\text { Share of Inside }}{\text { Directors }}$} & \multicolumn{2}{|c|}{$\frac{\text { Num. of External }}{\underline{\text { Directorships }}}$} \\
\hline & (1) & (2) & (3) & (4) & (5) & $(6)$ & (7) & $(8)$ & (9) & $(10)$ \\
\hline Constant & $\begin{array}{c}3.20 \\
(0.92) \\
\end{array}$ & $\begin{array}{c}4.68 \\
(1.04) \\
\end{array}$ & $\begin{array}{c}1.96 \\
(0.85) \\
\end{array}$ & $\begin{array}{c}3.37 \\
(0.95) \\
\end{array}$ & $\begin{array}{c}1.24 \\
(0.48) \\
\end{array}$ & $\begin{array}{c}1.30 \\
(0.55) \\
\end{array}$ & $\begin{array}{c}0.30 \\
(0.03) \\
\end{array}$ & $\begin{array}{c}0.29 \\
(0.04) \\
\end{array}$ & $\begin{array}{l}-6.77 \\
(0.62) \\
\end{array}$ & $\begin{array}{l}-5.49 \\
(0.67) \\
\end{array}$ \\
\hline $\begin{array}{l}\text { Indicator is } 1 \text { if the firm is } \\
\text { a commercial bank }\end{array}$ & $\begin{array}{c}5.34 \\
(0.39) \\
\end{array}$ & $\begin{array}{c}5.78 \\
(0.45) \\
\end{array}$ & $\begin{array}{c}5.25 \\
(0.36) \\
\end{array}$ & $\begin{array}{c}5.64 \\
(0.41) \\
\end{array}$ & $\begin{array}{c}0.09 \\
(0.20) \\
\end{array}$ & $\begin{array}{c}0.14 \\
(0.24) \\
\end{array}$ & $\begin{array}{l}-0.07 \\
(0.01) \\
\end{array}$ & $\begin{array}{l}-0.08 \\
(0.02)\end{array}$ & $\begin{array}{c}0.49 \\
(0.26) \\
\end{array}$ & $\begin{array}{c}0.76 \\
(0.29) \\
\end{array}$ \\
\hline $\begin{array}{l}\text { Indicator is } 1 \text { if the firm is } \\
\text { an insurance company }\end{array}$ & - & $\begin{array}{c}0.98 \\
(0.59) \\
\end{array}$ & - & $\begin{array}{l}1.05 \\
(0.54) \\
\end{array}$ & - & $\begin{array}{l}-0.08 \\
(0.31) \\
\end{array}$ & - & $\begin{array}{l}-0.03 \\
(0.02) \\
\end{array}$ & - & $\begin{array}{c}0.01 \\
(0.38) \\
\end{array}$ \\
\hline $\begin{array}{l}\text { Indicator is } 1 \text { if the firm is } \\
\text { other financial }\end{array}$ & - & $\begin{array}{c}1.66 \\
(1.11) \\
\end{array}$ & - & $\begin{array}{l}-0.49 \\
(1.02) \\
\end{array}$ & - & $\begin{array}{c}2.15 \\
(0.58) \\
\end{array}$ & - & $\begin{array}{c}0.08 \\
(0.04) \\
\end{array}$ & - & $\begin{array}{c}0.93 \\
(0.71) \\
\end{array}$ \\
\hline $\begin{array}{l}\text { Log of Market } \\
\text { Capitalization }\end{array}$ & $\begin{array}{c}1.10 \\
(0.12) \\
\end{array}$ & $\begin{array}{c}0.70 \\
(0.15) \\
\end{array}$ & $\begin{array}{c}0.85 \\
(0.11) \\
\end{array}$ & $\begin{array}{c}0.50 \\
(0.14) \\
\end{array}$ & $\begin{array}{c}0.25 \\
(0.06) \\
\end{array}$ & $\begin{array}{c}0.20 \\
(0.08) \\
\end{array}$ & $\begin{array}{l}-0.003 \\
(0.004) \\
\end{array}$ & $\begin{array}{l}-0.0004 \\
(0.0053) \\
\end{array}$ & $\begin{array}{c}1.10 \\
(0.08) \\
\end{array}$ & $\begin{array}{c}0.70 \\
(0.10) \\
\end{array}$ \\
\hline $\begin{array}{l}\text { Log of the Number of } \\
\text { Employees }\end{array}$ & - & $\begin{array}{c}0.61 \\
(0.14) \\
\end{array}$ & - & $\begin{array}{c}0.49 \\
(0.13) \\
\end{array}$ & - & $\begin{array}{c}0.13 \\
(0.07) \\
\end{array}$ & - & $\begin{array}{l}-0.004 \\
(0.005) \\
\end{array}$ & - & $\begin{array}{c}0.73 \\
(0.09) \\
\end{array}$ \\
\hline Number of observations & 680 & 591 & 680 & 591 & 680 & 591 & 680 & 591 & 680 & 591 \\
\hline Adjusted- $\mathrm{R}^{2}$ & 0.24 & 0.24 & 0.24 & 0.25 & 0.02 & 0.05 & 0.04 & 0.06 & 0.23 & 0.30 \\
\hline
\end{tabular}


Table 2 (continued): Estimates relating Board Size, Board Composition, and External Directorships of Officer-Directors (Insiders) for Financial and Non-Financial Firms in 1992

Panel B: Poisson and Logistic

Columns i-vi and ix-x contain Poisson estimates of the differences in board characteristics between financial and non-financial firms, controlling for firm size. Columns vii-viii contain OLS estimates of the logistic transformation of share of inside directors. Financial firms are classified as commercial banks, insurance companies, and other financials. Officer-directors or "inside" directors are members of a firm's board whose principal employer is that firm. Non-employee or "outside" directors are members of a firm's board whose principal employer is not that firm. External board memberships are the number of directorships on other Forbes 500 firms held by the inside directors of a firm. The dependent variables are listed over each pair of columns. Standard errors are in parentheses. The sample is drawn from Forbes 500 listings in 1992 (see Hallock 1997).

\begin{tabular}{|c|c|c|c|c|c|c|c|c|c|c|}
\hline \multirow[t]{2}{*}{$\begin{array}{l}\text { Dependent } \\
\text { Variable: }\end{array}$} & \multicolumn{2}{|c|}{ Board Size } & \multicolumn{2}{|c|}{$\frac{\text { Number of Outside }}{\underline{\text { Directors }}}$} & \multicolumn{2}{|c|}{$\frac{\text { Number of Inside }}{\underline{\text { Directors }}}$} & \multicolumn{2}{|c|}{$\begin{array}{c}\frac{\text { Logistic Transform }}{\text { of the Share of }} \\
\underline{\text { Inside Directors }}\end{array}$} & \multicolumn{2}{|c|}{$\frac{\text { Num. of External }}{\underline{\text { Directorships }}}$} \\
\hline & (1) & (2) & (3) & (4) & (5) & (6) & (7) & (8) & (9) & (10) \\
\hline Constant & $\begin{array}{l}1.78 \\
(0.07)\end{array}$ & $\begin{array}{c}1.90 \\
(0.08)\end{array}$ & $\begin{array}{l}1.45 \\
(0.08)\end{array}$ & $\begin{array}{c}1.60 \\
(0.10)\end{array}$ & $\begin{array}{c}0.53 \\
(0.15)\end{array}$ & $\begin{array}{c}0.57 \\
(0.16)\end{array}$ & $\begin{array}{l}-0.97 \\
(0.18)\end{array}$ & $\begin{array}{l}-1.04 \\
(0.20)\end{array}$ & $\begin{array}{l}-4.63 \\
(0.21)\end{array}$ & $\begin{array}{l}-3.38 \\
(0.23)\end{array}$ \\
\hline $\begin{array}{l}\text { Indicator is } 1 \text { if the firm is } \\
\text { a commercial bank }\end{array}$ & $\begin{array}{c}0.39 \\
(0.03)\end{array}$ & $\begin{array}{c}0.43 \\
(0.03)\end{array}$ & $\begin{array}{c}0.50 \\
(0.03)\end{array}$ & $\begin{array}{c}0.54 \\
(0.04)\end{array}$ & $\begin{array}{c}0.03 \\
(0.06)\end{array}$ & $\begin{array}{c}0.04 \\
(0.07)\end{array}$ & $\begin{array}{l}-0.42 \\
(0.07)\end{array}$ & $\begin{array}{l}-0.47 \\
(0.09)\end{array}$ & $\begin{array}{c}0.15 \\
(0.09)\end{array}$ & $\begin{array}{c}0.25 \\
(0.11)\end{array}$ \\
\hline $\begin{array}{l}\text { Indicator is } 1 \text { if the firm is } \\
\text { an insurance company }\end{array}$ & - & $\begin{array}{c}0.08 \\
(0.05) \\
\end{array}$ & - & $\begin{array}{c}0.12 \\
(0.05) \\
\end{array}$ & - & $\begin{array}{l}-0.03 \\
(0.09)\end{array}$ & - & $\begin{array}{l}-0.18 \\
(0.11) \\
\end{array}$ & - & $\begin{array}{l}-0.17 \\
(0.16) \\
\end{array}$ \\
\hline $\begin{array}{l}\text { Indicator is } 1 \text { if the firm is } \\
\text { other financial }\end{array}$ & - & $\begin{array}{c}0.13 \\
(0.08)\end{array}$ & - & $\begin{array}{l}-0.06 \\
(0.11)\end{array}$ & - & $\begin{array}{c}0.52 \\
(0.13)\end{array}$ & - & $\begin{array}{c}0.45 \\
(0.22)\end{array}$ & - & $\begin{array}{l}-0.50 \\
(0.20)\end{array}$ \\
\hline $\begin{array}{l}\text { Log of Market } \\
\text { Capitalization }\end{array}$ & $\begin{array}{c}0.09 \\
(0.01)\end{array}$ & $\begin{array}{c}0.05 \\
(0.01)\end{array}$ & $\begin{array}{c}0.09 \\
(0.01)\end{array}$ & $\begin{array}{c}0.05 \\
(0.01)\end{array}$ & $\begin{array}{c}0.08 \\
(0.02)\end{array}$ & $\begin{array}{c}0.06 \\
(0.02)\end{array}$ & $\begin{array}{l}-0.01 \\
(0.02)\end{array}$ & $\begin{array}{c}0.004 \\
(0.029)\end{array}$ & $\begin{array}{c}0.63 \\
(0.02)\end{array}$ & $\begin{array}{c}0.35 \\
(0.03)\end{array}$ \\
\hline $\begin{array}{l}\text { Log of the Number of } \\
\text { Employees }\end{array}$ & - & $\begin{array}{c}0.05 \\
(0.01) \\
\end{array}$ & - & $\begin{array}{c}0.05 \\
(0.01) \\
\end{array}$ & - & $\begin{array}{c}0.04 \\
(0.02) \\
\end{array}$ & - & $\begin{array}{l}-0.02 \\
(0.03)\end{array}$ & - & $\begin{array}{r}0.37 \\
(0.03) \\
\end{array}$ \\
\hline Number of observations & 680 & 591 & 680 & 591 & 680 & 591 & 680 & 591 & 680 & 591 \\
\hline$p$-value of chi $^{2}$ for regress. & $<0.01$ & $<0.01$ & $<0.01$ & $<0.01$ & $<0.01$ & $<0.01$ & - & - & $<0.01$ & $<0.01$ \\
\hline Pseudo-R ${ }^{2}$ & 0.06 & 0.06 & 0.07 & 0.07 & 0.01 & 0.02 & 0.04 & 0.05 & 0.22 & 0.27 \\
\hline
\end{tabular}


Table 3. Characteristics of firms with a bank executive on the board and with an executive on a bank's board in 1992.

This table displays median values for a set of firm characteristics, as measured in 1992. For some characteristics, medians are calculated for a partial sample. All data except the standard deviation of stock returns are taken from Compustat. Total assets are in millions of 1992 dollars. The standard deviation of monthly stock price returns measured from January 1988 to December 1991 , from CRSP. Tangible Assets includes property, plant, and equipment. Commercial Paper Rating is one if the firm has such a rating and zero otherwise. Notes payable are debt obligations with original maturity less than one year. Short-term debt is total debt maturing within one year. Debt is total book value of debt, including both long- and short-term debt. Liquid assets includes all current assets. The dividend/net income variable is defined only for firms with positive net income. The interest coverage ratio equals pre-tax income plus interest expense divided by interest expense.

\begin{tabular}{|c|c|c|c|c|c|c|c|c|c|}
\hline & \multirow[b]{2}{*}{$\begin{array}{c}\text { Any Board } \\
\text { Connection } \\
\text { to a Bank } \\
(\mathrm{N}=230)\end{array}$} & \multirow[b]{2}{*}{$\begin{array}{l}\text { Firms } \\
\text { with a } \\
\text { Banker } \\
\text { Director } \\
(\mathrm{N}=75)\end{array}$} & \multirow[b]{2}{*}{$\begin{array}{c}\text { Executive } \\
\text { on Bank's } \\
\text { Board } \\
(\mathrm{N}=94)\end{array}$} & \multirow[b]{2}{*}{$\begin{array}{c}\text { Board } \\
\text { links both } \\
\text { ways } \\
(\mathrm{N}=61)\end{array}$} & \multirow[b]{2}{*}{$\begin{array}{l}\text { No Board } \\
\text { Link to a } \\
\text { Bank } \\
(\mathrm{N}=200)\end{array}$} & \multicolumn{3}{|c|}{ Kruskal Wallis Test ( $p$-Value) } & \multirow[b]{2}{*}{$\begin{array}{l}\text { Column (4) } \\
\text { vs. column } \\
\text { (5) }\end{array}$} \\
\hline & & & & & & $\begin{array}{c}\text { Column } \\
\text { (1) vs. } \\
\text { Column } \\
\text { (5) }\end{array}$ & $\begin{array}{l}\text { Column } \\
\text { (2) vs. } \\
\text { Column } \\
\quad(5)\end{array}$ & $\begin{array}{l}\text { Column } \\
\text { (3) vs. } \\
\text { column } \\
\text { (5) }\end{array}$ & \\
\hline & (1) & $(2)$ & (3) & (4) & $(5)$ & (6) & (7) & $(8)$ & (9) \\
\hline Total assets & 4,599 & 2,946 & 4,695 & 6,627 & 2,213 & $<0.01$ & 0.07 & $<0.01$ & $<0.01$ \\
\hline Std. Dev. of stock return & 0.072 & 0.076 & 0.069 & 0.070 & 0.087 & $<0.01$ & 0.02 & $<0.01$ & $<0.01$ \\
\hline Tangible assets / assets & 0.460 & 0.460 & 0.432 & 0.525 & 0.337 & $<0.01$ & $<0.01$ & $<0.01$ & $<0.01$ \\
\hline Short-term debt / debt & 0.145 & 0.096 & 0.168 & 0.168 & 0.143 & 0.50 & 0.03 & 0.38 & 0.77 \\
\hline Debt / assets & 0.293 & 0.290 & 0.285 & 0.309 & 0.236 & $<0.01$ & 0.10 & 0.03 & $<0.01$ \\
\hline Cash / assets & 0.027 & 0.040 & 0.031 & 0.016 & 0.054 & $<0.01$ & 0.04 & $<0.01$ & $<0.01$ \\
\hline Liquid assets / assets & 0.317 & 0.294 & 0.356 & 0.231 & 0.455 & $<0.01$ & $<0.01$ & $<0.01$ & $<0.01$ \\
\hline Share with a $\mathrm{CP}$ rating & 0.643 & 0.493 & 0.691 & 0.754 & 0.390 & $<0.01$ & 0.19 & $<0.01$ & $<0.01$ \\
\hline Interest coverage ratio & 5.800 & 5.681 & 6.270 & 5.710 & 7.347 & 0.04 & 0.03 & 0.30 & 0.11 \\
\hline
\end{tabular}


Table 4. Probit estimates relating firm characteristics to the presence of a board connection in 1992.

The coefficients reported are the marginal effects, estimated from a probit model, of a one unit change from the mean of each independent variable on the probability of having a banker on the board. The dependent variable is one if the firm has a banker on its board in 1992 or an executive on a bank's board, and zero otherwise. Firm size is measured as the log of assets. Volatility is measured as the standard deviation of monthly stock price returns from January 1988 to December 1991. Tangible assets include property, plant, and equipment. Commercial Paper Rating is one if the firm has such a rating, and zero otherwise. Short-term debt is debt with less than one year maturity. $N=430$, except for column (4), which contains 420. Standard errors are in parentheses. P-values for the F-test for joint significance of linear and non-linear standard deviation terms, and for the regression as a whole, are reported at the bottom of the table.

\begin{tabular}{|c|c|c|c|c|}
\hline \multirow[b]{2}{*}{ Variables } & \multicolumn{4}{|c|}{ Alternative Model Specifications } \\
\hline & (1) & (2) & (3) & (4) \\
\hline $\begin{array}{l}\text { Standard deviation of monthly } \\
\text { stock returns }\end{array}$ & $\begin{array}{l}-4.33 \\
(0.92) \\
\end{array}$ & $\begin{array}{c}1.28 \\
(3.94)\end{array}$ & $\begin{array}{c}3.85 \\
(4.20) \\
\end{array}$ & $\begin{array}{c}3.29 \\
(4.26) \\
\end{array}$ \\
\hline $\begin{array}{l}\text { Square of standard deviation of } \\
\text { monthly stock returns }\end{array}$ & - & $\begin{array}{l}-29.96 \\
(19.84) \\
\end{array}$ & $\begin{array}{l}-36.58 \\
(20.73)\end{array}$ & $\begin{array}{l}-35.45 \\
(21.05)\end{array}$ \\
\hline Log of assets & $\begin{array}{c}0.11 \\
(0.03) \\
\end{array}$ & $\begin{array}{c}0.12 \\
(0.03) \\
\end{array}$ & $\begin{array}{c}0.09 \\
(0.03) \\
\end{array}$ & $\begin{array}{c}0.10 \\
(0.03) \\
\end{array}$ \\
\hline $\begin{array}{l}\text { Indicator for low interest } \\
\text { coverage ratio }\end{array}$ & $\begin{array}{c}0.06 \\
(0.09) \\
\end{array}$ & $\begin{array}{c}0.06 \\
(0.09) \\
\end{array}$ & $\begin{array}{c}0.08 \\
(0.09) \\
\end{array}$ & $\begin{array}{c}0.09 \\
(0.10) \\
\end{array}$ \\
\hline Tangible assets / assets & - & - & $\begin{array}{c}0.36 \\
(0.12) \\
\end{array}$ & $\begin{array}{c}0.33 \\
(0.14) \\
\end{array}$ \\
\hline Commercial paper rating & - & - & $\begin{array}{c}0.14 \\
(0.06) \\
\end{array}$ & $\begin{array}{c}0.13 \\
(0.06) \\
\end{array}$ \\
\hline $\begin{array}{l}\text { Debt / market value of equity } \\
\text { plus debt }\end{array}$ & - & - & - & $\begin{array}{l}-0.10 \\
(0.16) \\
\end{array}$ \\
\hline Short-term debt / debt & - & - & - & $\begin{array}{l}-0.16 \\
(0.12)\end{array}$ \\
\hline $\begin{array}{l}\mathrm{p} \text {-value for standard deviation } \\
\text { of monthly returns }\end{array}$ & - & $<0.01$ & $<0.01$ & 0.01 \\
\hline $\mathrm{p}$-value for $\chi^{2}$ for regression & $<0.01$ & $<0.01$ & $<0.01$ & $<0.01$ \\
\hline Pseudo- $\mathrm{R}^{2}$ & 0.106 & 0.109 & 0.132 & 0.135 \\
\hline
\end{tabular}


Table 5. Multinomial logit model relating firm and industry characteristics to the presence of a link from the firm to the bank via the board of directors.

The dependent variable is classified into four categories: no link to the bank $(n=200)$, a banker on the firm's board only ( $\mathrm{n}=75)$, an executive from the firm on the bank's board only $(\mathrm{N}=94)$, or a board link from the firm to a bank in both of these ways $(n=61)$. Standard errors are in parentheses. Three joint tests are reported at the bottom of the table. First, the P-values for the F-test for joint significance of linear and non- linear standard deviation terms. Second, the Pvalue for the joint significance of the coefficients for each of the three segments. Third, the Pvalue for the joint significance of the regression as a whole.

\begin{tabular}{|c|c|c|c|}
\hline Variables & $\begin{array}{c}\text { Firm has a } \\
\text { Banker Director }\end{array}$ & $\begin{array}{l}\text { Firm has an } \\
\text { executive on a } \\
\text { Bank's Board }\end{array}$ & $\begin{array}{l}\text { Firm has both a } \\
\text { Banker Director } \\
\text { and an executive } \\
\text { a Bank' Board }\end{array}$ \\
\hline $\begin{array}{l}\text { Standard deviation of monthly stock } \\
\text { returns }\end{array}$ & $\begin{array}{c}30.19 \\
(23.32)\end{array}$ & $\begin{array}{l}-11.58 \\
(22.05)\end{array}$ & $\begin{array}{c}76.79 \\
(44.29)\end{array}$ \\
\hline $\begin{array}{l}\text { Square of standard deviation of } \\
\text { monthly stock returns }\end{array}$ & $\begin{array}{l}-214.26 \\
(122.66)\end{array}$ & $\begin{array}{c}-21.62 \\
(108.49)\end{array}$ & $\begin{array}{l}-553.63 \\
(266.83)\end{array}$ \\
\hline Log of assets & $\begin{array}{c}0.04 \\
(0.17) \\
\end{array}$ & $\begin{array}{c}0.45 \\
(0.16) \\
\end{array}$ & $\begin{array}{c}0.84 \\
(0.17) \\
\end{array}$ \\
\hline $\begin{array}{l}\text { Indicator for low interest coverage } \\
\text { ratio }\end{array}$ & $\begin{array}{c}0.31 \\
(0.56)\end{array}$ & $\begin{array}{c}0.45 \\
(0.55)\end{array}$ & $\begin{array}{c}0.33 \\
(0.63)\end{array}$ \\
\hline Tangible assets / assets & $\begin{array}{r}1.49 \\
(0.81)\end{array}$ & $\begin{array}{r}1.03 \\
(0.69)\end{array}$ & $\begin{array}{c}2.13 \\
(0.89)\end{array}$ \\
\hline Commercial paper rating & $\begin{array}{c}0.21 \\
(0.30) \\
\end{array}$ & $\begin{array}{c}0.76 \\
(0.31) \\
\end{array}$ & $\begin{array}{c}0.87 \\
(0.39) \\
\end{array}$ \\
\hline Debt / market value of equity plus debt & $\begin{array}{l}-0.07 \\
(0.91) \\
\end{array}$ & $\begin{array}{l}-0.57 \\
(0.88) \\
\end{array}$ & $\begin{array}{l}-0.51 \\
(0.95) \\
\end{array}$ \\
\hline Short-term debt / debt & $\begin{array}{l}-1.19 \\
(0.83) \\
\end{array}$ & $\begin{array}{l}-0.24 \\
(0.61) \\
\end{array}$ & $\begin{array}{r}-0.80 \\
(0.88) \\
\end{array}$ \\
\hline $\begin{array}{l}\text { p-value for joint significance of all } \\
\text { coefficient, separate segments }\end{array}$ & 0.01 & $<0.01$ & $<0.01$ \\
\hline $\begin{array}{l}\text { p-value for joint significance of std. dev. } \\
\text { of monthly returns, separate segments }\end{array}$ & 0.09 & 0.03 & 0.04 \\
\hline $\mathrm{p}$-value for $\chi^{2}$ for regression & \multicolumn{3}{|c|}{$<0.01$} \\
\hline Pseudo- $\mathrm{R}^{2}$ & \multicolumn{3}{|c|}{0.110} \\
\hline
\end{tabular}


Table 6. Regression relating firm characteristics to the share of bank loans from a connected bank between 1992 and 1994.

The dependent variables is the share of loans in which the bank connected to the firm by a board link acts as the lead arranger. The loan data come from LPC's Dealscan and must have been made between 1992 and 1994. In order for a firm to appear in the sample, it must have a connection to a bank and it must have some loan data available on Dealscan between 1992 and 1994. Standard errors are in parentheses.

\begin{tabular}{|c|c|c|c|c|}
\hline \multirow[b]{2}{*}{ Variables } & \multicolumn{4}{|c|}{ Alternative Specifications } \\
\hline & $(1)$ & $(2)$ & (3) & (4) \\
\hline $\begin{array}{l}\text { Standard deviation of monthly stock } \\
\text { returns }\end{array}$ & $\begin{array}{c}2.54 \\
(1.32) \\
\end{array}$ & $\begin{array}{l}13.61 \\
(5.02) \\
\end{array}$ & $\begin{array}{l}16.30 \\
(6.81) \\
\end{array}$ & $\begin{array}{l}14.53 \\
(6.94) \\
\end{array}$ \\
\hline $\begin{array}{l}\text { Square of standard deviation of } \\
\text { monthly stock returns }\end{array}$ & - & $\begin{array}{l}-65.69 \\
(27.15) \\
\end{array}$ & $\begin{array}{l}-82.65 \\
(38.23) \\
\end{array}$ & $\begin{array}{l}-74.39 \\
(38.99) \\
\end{array}$ \\
\hline Log of assets & $\begin{array}{c}0.08 \\
(0.03) \\
\end{array}$ & $\begin{array}{c}0.08 \\
(0.03) \\
\end{array}$ & $\begin{array}{c}0.09 \\
(0.03) \\
\end{array}$ & $\begin{array}{c}0.10 \\
(0.03) \\
\end{array}$ \\
\hline $\begin{array}{l}\text { Indicator for low interest coverage } \\
\text { ratio }\end{array}$ & $\begin{array}{l}-0.21 \\
(0.08) \\
\end{array}$ & $\begin{array}{l}-0.20 \\
(0.08) \\
\end{array}$ & $\begin{array}{l}-0.22 \\
(0.07) \\
\end{array}$ & $\begin{array}{l}-0.14 \\
(0.10) \\
\end{array}$ \\
\hline Tangible assets / assets & - & - & $\begin{array}{c}0.06 \\
(0.16) \\
\end{array}$ & $\begin{array}{c}0.05 \\
(0.17) \\
\end{array}$ \\
\hline Commercial paper rating & - & - & $\begin{array}{l}-0.07 \\
(0.07) \\
\end{array}$ & $\begin{array}{l}-0.05 \\
(0.08) \\
\end{array}$ \\
\hline Debt / market value of equity plus debt & - & - & - & $\begin{array}{l}-0.24 \\
(0.19) \\
\end{array}$ \\
\hline Short-term debt / debt & - & - & - & $\begin{array}{l}-0.48 \\
(0.20)\end{array}$ \\
\hline Dependent variable mean & 0.16 & 0.16 & 0.16 & 0.16 \\
\hline $\begin{array}{l}\text { p-value for standard deviation of } \\
\text { monthly returns }\end{array}$ & - & 0.02 & 0.04 & 0.09 \\
\hline p-value for regression & 0.01 & 0.01 & 0.04 & 0.01 \\
\hline $\mathrm{N}$ & 136 & 136 & 136 & 134 \\
\hline
\end{tabular}


Table 7. Regression relating firm characteristics to the share of bank loans from a connected bank between 1992 and 1994.

The dependent variables are: (1) the share of loans in which the bank that is connected to the firm by having a banker on the firm's board acts as the lead arranger; (2) the share of loans in which the bank on whose board an executive from the borrower serves acts as the lead arranger. The loan data come from LPC's Dealscan and must have been made between 1992 and 1994. In order for a firm to appear in the sample, it must have a connection to a bank and it must have some loan data available on Dealscan between 1992 and 1994. Standard errors are in parentheses.

\begin{tabular}{|c|c|c|c|c|}
\hline \multirow{2}{*}{$\begin{array}{l}\text { Variables } \\
\text { Standard deviation of monthly } \\
\text { stock returns }\end{array}$} & \multicolumn{2}{|c|}{$\begin{array}{l}\text { Share of loans from bank that } \\
\text { serves on the firm's board }\end{array}$} & \multicolumn{2}{|c|}{$\begin{array}{c}\text { Share of loans from bank } \\
\text { on whose board the } \\
\text { firm has an executive } \\
\text { serving }\end{array}$} \\
\hline & $\begin{array}{l}15.82 \\
(6.74) \\
\end{array}$ & $\begin{array}{l}15.61 \\
(7.35) \\
\end{array}$ & $\begin{array}{c}4.74 \\
(11.09) \\
\end{array}$ & $\begin{array}{c}0.91 \\
(11.18) \\
\end{array}$ \\
\hline $\begin{array}{l}\text { Square of standard deviation of } \\
\text { monthly stock returns }\end{array}$ & $\begin{array}{l}-90.07 \\
(36.80) \\
\end{array}$ & $\begin{array}{l}-89.88 \\
(40.01) \\
\end{array}$ & $\begin{array}{l}-10.92 \\
(70.04) \\
\end{array}$ & $\begin{array}{c}8.75 \\
(71.00) \\
\end{array}$ \\
\hline Log of assets & $\begin{array}{c}0.05 \\
(0.04)\end{array}$ & $\begin{array}{c}0.05 \\
(0.04) \\
\end{array}$ & $\begin{array}{c}0.08 \\
(0.03) \\
\end{array}$ & $\begin{array}{c}0.09 \\
(0.03) \\
\end{array}$ \\
\hline $\begin{array}{l}\text { Indicator for low interest } \\
\text { coverage ratio }\end{array}$ & $\begin{array}{l}-0.09 \\
(0.13)\end{array}$ & $\begin{array}{l}-0.05 \\
(0.17) \\
\end{array}$ & $\begin{array}{l}-0.24 \\
(0.08)\end{array}$ & $\begin{array}{l}-0.13 \\
(0.09) \\
\end{array}$ \\
\hline Tangible assets / assets & $\begin{array}{c}0.08 \\
(0.20) \\
\end{array}$ & $\begin{array}{c}0.02 \\
(0.21) \\
\end{array}$ & $\begin{array}{l}-0.09 \\
(0.20)\end{array}$ & $\begin{array}{l}-0.21 \\
(0.23) \\
\end{array}$ \\
\hline Commercial paper rating & $\begin{array}{c}0.01 \\
(0.09) \\
\end{array}$ & $\begin{array}{c}0.02 \\
(0.09) \\
\end{array}$ & $\begin{array}{l}-0.09 \\
(0.10) \\
\end{array}$ & $\begin{array}{l}-0.06 \\
(0.10) \\
\end{array}$ \\
\hline $\begin{array}{l}\text { Debt / market value of equity } \\
\text { plus debt }\end{array}$ & - & $\begin{array}{l}-0.08 \\
(0.25) \\
\end{array}$ & - & $\begin{array}{l}-0.30 \\
(0.23) \\
\end{array}$ \\
\hline Short-term debt / debt & - & $\begin{array}{l}-0.44 \\
(0.30) \\
\end{array}$ & - & $\begin{array}{l}-0.48 \\
(0.22) \\
\end{array}$ \\
\hline Dependent variable mean & 0.17 & 0.17 & 0.12 & 0.12 \\
\hline $\begin{array}{l}\text { p-value for standard deviation } \\
\text { of monthly returns }\end{array}$ & 0.05 & 0.08 & 0.36 & 0.56 \\
\hline p-value for regression & 0.24 & 0.30 & 0.08 & 0.10 \\
\hline $\mathrm{N}$ & 80 & 80 & 93 & 91 \\
\hline
\end{tabular}


Table 8. Regression relating the interest rate on loans to connected borrowers to firm characteristics, loan characteristics, and the presence of a connection, 1992 and 1994.

This table contains GLS random-effects estimates of the impact of board connections on the pricing of bank loans from 1992 to 1994 (there are sometimes more than one loan to a borrowers). The dependent variable is the "drawn all-in spread" of each loan. Each sample contains only firms with a connection to a bank by having a banker on its board or having an executive on a bank's board. The drawn all-in spread is defined as the mark-up over LIBOR for the loan for amounts actually borrowed, in basis points. The borrowing data are from the Loan Pricing Corporation's Dealscan database. All specifications include a number of individual loan characteristics from the Loan Pricing Corporation data: log of loan size, log of maturity, and indicators for revolving credit agreements, secured loans (as well as an indicator if information about security is missing), and stated purpose of the loan. Standard errors are in parentheses.

\begin{tabular}{|c|c|c|c|}
\hline Variable & $\begin{array}{l}\text { Firms with any } \\
\text { board connection }\end{array}$ & $\begin{array}{c}\text { Firms with a } \\
\text { Banker on their } \\
\text { own Board }\end{array}$ & $\begin{array}{c}\text { Firms with an } \\
\text { Executive on a Bank's } \\
\text { Board }\end{array}$ \\
\hline $\begin{array}{l}\text { Indicator equal to } 1 \text { for loans } \\
\text { made by a connected bank }\end{array}$ & $\begin{array}{c}7.31 \\
(7.08) \\
\end{array}$ & $\begin{array}{c}21.71 \\
(12.95) \\
\end{array}$ & $\begin{array}{l}-5.97 \\
(9.29) \\
\end{array}$ \\
\hline $\begin{array}{l}\text { Standard deviation of } \\
\text { monthly stock returns }\end{array}$ & $\begin{array}{c}440.03 \\
(185.55) \\
\end{array}$ & $\begin{array}{c}391.29 \\
(252.83)\end{array}$ & $\begin{array}{c}367.17 \\
(191.92) \\
\end{array}$ \\
\hline Log of assets & $\begin{array}{c}9.95 \\
(4.20) \\
\end{array}$ & $\begin{array}{l}11.04 \\
(6.87) \\
\end{array}$ & $\begin{array}{c}9.67 \\
(4.23) \\
\end{array}$ \\
\hline $\begin{array}{l}\text { Indicator for low interest } \\
\text { coverage ratio }\end{array}$ & $\begin{array}{c}29.21 \\
(11.97) \\
\end{array}$ & $\begin{array}{r}34.30 \\
(20.99) \\
\end{array}$ & $\begin{array}{c}33.97 \\
(10.48) \\
\end{array}$ \\
\hline Tangible assets / assets & $\begin{array}{c}-6.25 \\
(17.29) \\
\end{array}$ & $\begin{array}{c}2.98 \\
(22.47) \\
\end{array}$ & $\begin{array}{c}-9.27 \\
(17.99) \\
\end{array}$ \\
\hline Commercial paper rating & $\begin{array}{l}-10.23 \\
(7.08)\end{array}$ & $\begin{array}{l}-13.33 \\
(11.24)\end{array}$ & $\begin{array}{l}-15.20 \\
(7.36)\end{array}$ \\
\hline $\begin{array}{l}\text { Debt / market value of } \\
\text { equity plus debt }\end{array}$ & $\begin{array}{c}24.26 \\
(25.76) \\
\end{array}$ & $\begin{array}{c}0.33 \\
(32.85) \\
\end{array}$ & $\begin{array}{r}22.99 \\
(22.93) \\
\end{array}$ \\
\hline Short-term debt / debt & $\begin{array}{r}11.28 \\
(25.76) \\
\end{array}$ & $\begin{array}{r}86.65 \\
(51.08) \\
\end{array}$ & $\begin{array}{l}-23.91 \\
(22.82) \\
\end{array}$ \\
\hline $\begin{array}{l}\text { Dependent variable mean } \\
\text { (Basis point spread over } \\
\text { LIBOR) }\end{array}$ & 60.81 & 58.65 & 62.50 \\
\hline p-value for regression & $<0.01$ & $<0.01$ & $<0.01$ \\
\hline $\mathrm{N}$ & 285 & 125 & 160 \\
\hline $\mathrm{R}^{2}$ & 0.67 & 0.53 & 0.80 \\
\hline
\end{tabular}

